vestigations of the fresh-water species in the tanks at Bombay. The clear and lucid manner of investigation detailed by Prof. Grant in the Edinburgh Newe Philosophical Fournal (1826.27) might be held as a pattern for investigators, but he appears to be almost entirely lost sight of.

Again, as regards the animals of Grantia compressa, Prof. Reay Greene certainly preceded both Prof. Clark and Mr. Carter in his investigations, and has figured these monociliated animals in his handbook, published in 1859 , p. 31 , fig. 6 . The figures are on the same scale as those given by Mr. Carter, and indeed some of the groups figured are so much like those given by Mr. Carter in the "Annals," pl. I, sqr. 13, $a, g$, $h$, that it would be difficult to separate them, and the same may be said of Fig. 4I of Prof. Clark's in "Ann. Nat. Hist" pl. 6, 1868. The only difference being the want of the funnel-shaped mouth, which seems to have escaped the observation of Prof. Greene, prohably owing to want of definition in the instrument used in the investigation. Now there is an amount of credit due to the first demonstrator of these animals, which, so far as I have seen, does not appear to have been accorded to him; and I therefore take the liberty of directing attention to this fact. I do not know Prof. Greene, and therefore do not take up this matter on personal grounds, but only in fairness due from one scientific man to another, and I hope my friend Carter will talse this in the spirit it is intended.

EDWARD PARFITT

Exeter, July 8

\section{Cramming for Examinations}

I ENCLOSE one or two bonâ fide extracts from "Middle Class" examination papers which have during the past few weeks come under my notice officially.

I do not wish thereby to reflect so much on the candidates as upon the mode of teaching in Middle Class schools, which produces such results.

As might be expected, where evidence of "cramming" from a text-book and want of practical knowledge are equally manifest, some of the answers in the papers from which these are selected are pretty good-but what can be the real value of knowledge of this sort?

The questions are sufficiently indicated by the answers.

\section{Candidate A}

Chlorine may be taken from decayed vegetable matter and animal matter, also manure. . . . It is used for killing insects, it is compounded with lime, and is very good when compounded with lime for the manuring of fields. Lime is chiefly formed from Chlorine.

\section{CANDidate B.}

Chlorine is prepared by mixing $\mathrm{Ca} \mathrm{Cl}_{2}$ with $\mathrm{H}_{2} \mathrm{O}$ $\mathrm{CaCl}+\mathrm{H}_{2} \mathrm{O}=\mathrm{CaO}+\mathrm{H}_{2}+\mathrm{Cl}_{2}$

Chlorine is a colourless invisible gas. Has no odour nor taste. - . Hydrochloric acid is prepared as follows$\mathrm{CaCl}+\mathrm{H}_{2} \mathrm{O}=\mathrm{CaO}+2 \mathrm{H} \mathrm{Cl}$

\section{Candidate $\mathrm{C}$}

Carbon is an elementary substance, it is one of the constituents of the atmosphere, it is found in lime and pits among the coal. When the lime is soaked with water the carbon escapes out and the lime moulds away.

\section{AN EXaminer}

\section{Great Heat in Iceland during the present Summer}

MR. R. M. SMITf has received a note from Dr. Hjaltelin, Corresponding Member of the Scottish Meteorological Society at Reykjavik, dated June 30, of which the following is an extract :-

"We have now the most excellent season you can imagine in these latitudes, the average temperature for this month (June) being as high as $59^{\circ}$, wich is $12^{\circ}$ higher than the mean temperature of the past four Junes. I was yes erday near the Hengil Mountain, just at that place where we pitched our tent last time you were here, and the heat was quite unsupportable in the valleys. The wind has been continually blowing from the southwest. Some Englishmen setting out for the Geyser will have something to tell of the extraordinary heat we have at present." AleXaNDER BUCHAN
The Late Thunderstorm

An ash tree in the garden attached to the farmhouse of Wester Cringate, near Fintry, struck by lightning on the 20 th of June, presents a singular appearance.

A bout 20 ft. from the ground a large branch has been torn from the trunk. The bark has been neatly peeled off for a few feet above and below the place from which the branch shot out. The wood has been first struck a little above the branch, and shows a clean cut, such as might have been made by a sharp-edged tool, as if a chisel three inches broad had been driven into the wood for about four inches. The branch itself has beent torn, not cut, and a stripe of the trunk about two feet long below the branch has also been torn out.

For the next four or five feet the tree has suffered no damage of any kind, but after that space the trunk bears six parallel downward scars, varying in length from two to five feet. The scars do not all begin or end at the same beight, although each might be cut in some point by a horizontal plane passing through the tree. They spread over about half the circumference of the trunk, and can all, or nearly all, be seen from one standpoint. The most striking circumstance, however, is the almost perfect parallelism of the scars, which are not vertical, but a little twisted round the trunk like the rifling of an Armstrong gun, the rifling in this case being on the outside of the barrel. Six chisels of about half an inch in breadth seem to have ploughed into the wood, tearing off at the same time rather broader stripes of the bark. Towards their lower ends the three right-hand scars cease to be quite parallel, and tend to converge ; but all three die out before the convergence takes place, and the tree for the next two feet or so is unscathed. Five feet from the ground (at about the point at which the three scars would converge, if produced) a single rut cutting deeply into the wood commences, which continues down to the soil.

The garden wall (which is a "dry-stone dyke," i.e. of loose uncemented stones) passes some three feet behind the tree, on the side directly opposite to that on which the markings above described occur. Outside of this garden the lightning has ploughed two pretty deep parallel ruts through the grassy soil some four feet apart, and stretching from the foot of the wall to the edge of a ditch, a distance of three feet. These ruts are the last observable traces of the passage of the lightning, and were probably made by the currents which engraved the three left-hand scars on the tree. Of course it is impossible to decide whether the currents passed through the open wall, or down the outside of it.

Three sheep on the neighbouring farm of Spittalhill were killed in the same thunderstorm. Their carcases were found lying in a line and were very much swollen, but bore no external marks of injury. A small patch of wool had been stripped from the flank of one of them, but probably this had no connection with the cause of death.

Geological Survey, Fintry by Glasgow, July 5

\section{Saturn's Rings}

As you have favoured my work on "Saturn's Rings and the Sun "with criticism, I feel sure that as that criticism is adverse to my views, you will in fairness allow me to reply to it.

I will do so in detail. Your reviewer commences very much under the impression that Prof. Clerk Maxwell having investigated the "Stability of Saturn's Rings," no one else is to venture into any discussion touching on their nature or origin. In fact he issues a caveat-Prof. Clerk Maxwell has conclu ted the subject! N'ext he asserts that I have not seen the Professor's work, becaune I ascribe to the perusal of Mr. Proctor's "Saturn and its System," the enlistment of my "interest in favour of the Satellite Theory." This is surely beyond his province, as I am free to choose my own point of starting. Mr. Proctor's work interested me, and so did Mr. Clerk Maxwell's, but the former elicited my work, the latter did not.

He next accuses me of placing too great faith in figures, and shows surprise at my giving the hourly rate of the solar motion to a mile, and the solar parallax to four places of decimals. The solar motion is that given by the Herschels, and the solar parallax by several observers. He is hard to please. But my reviewer has unfortunately missed the point of my arguments. The actuai velocity of this solar motion is perfectly immaterial; indeed, had he followed the reasoning, he would have seen how pointless are his objections. As regards my arguments in favour of the meteoric theory of
the sun, the reviewer is equally inaccurate. As to my being 